\title{
M protein from Streptococcus pyogenes induces tissue factor expression and pro-coagulant activity in human monocytes
}

Correspondence

Lisa I. Påhlman

Lisa.Pahlman@med.lu.se

Received 9 October 2006

Revised 23 April 2007

Accepted 7 May 2007

\section{Lisa I. PåhIman, Erik Malmström, Matthias Mörgelin and Heiko Herwald}

Department of Clinical Sciences, Lund, Section for Clinical and Experimental Infection Medicine, Lund University, SE-22184 Lund, Sweden

\begin{abstract}
Invasive infections caused by the important pathogen Streptococcus pyogenes are often associated with disturbed blood coagulation in the human host, and may in severe cases develop into the life-threatening condition disseminated intravascular coagulation. In this study, the addition of M1 protein to human blood or purified peripheral blood mononuclear cells led to a dose-dependent increase of pro-coagulant activity, which was mediated by an upregulation of tissue factor on monocytes. Analysis of the resulting clots by transmission electron microscopy revealed that the cells were covered with a fibrin network that seemed to originate from the cell surface. Taken together, the results imply an important role for $\mathrm{M}$ proteins in the induction of haemostatic disorders in invasive streptococcal infectious diseases.
\end{abstract}

\section{INTRODUCTION}

Sepsis is a severe and often life-threatening condition caused by a systemic activation of the immune system in response to microbial infection. As a result, the infected host can release pathological levels of pro-inflammatory mediators such as cytokines, chemokines and reactive oxygen species, which may lead to haemodynamic rearrangements that ultimately can progress into shock (Riedemann et al., 2003; Van Amersfoort et al., 2003). Notably, septic patients often suffer from varying degrees of local and systemic disturbed haemostasis that can develop into disseminated intravascular coagulation (DIC), a condition characterized by a massive and simultaneous induction of thrombosis and fibrinolysis. It is currently believed that DIC is mainly induced by an activation of the extrinsic pathway, also known as the tissue factor (TF)driven pathway of coagulation (Levi et al., 2003). Under these conditions, the systemic activation of the extrinsic pathway can lead to the generation of microthrombi that deposit in various organs. In severe cases, thrombus formation will also cause consumption of coagulation factors and platelets, and as a consequence, secondary bleeding may occur that can lead to multiple organ failure and death.

$\mathrm{TF}$ is a transmembrane protein that binds to circulating factor VII/VIIa (F VII/VIIa). The TF/F VIIa complex subsequently activates factor X (F X) and factor IX (F IX),

Abbreviations: DIC, disseminated intravascular coagulation; F, factor; LTA, lipoteichoic acid; PAB, peptostreptococcal albumin-binding protein; PBMCs, peripheral blood mononuclear cells; PG, peptidoglycan; TF, tissue factor; TFPI, tissue factor pathway inhibitor. leading to thrombin generation, fibrin deposition and platelet activation. TF is found at high levels in adventitial fibroblasts surrounding blood vessels, where it forms a protective barrier against haemorrhage upon vessel injury (Mackman, 2006). While the protein is normally not exposed to human blood, TF can be upregulated on the surface of activated monocytes under pathological conditions (Mackman, 2006), and it has been suggested that in severe infectious diseases, bacteria-induced expression of TF in these cells is a hallmark of DIC (for a review see Doshi \& Marmur, 2002). It should be mentioned that various infection models have shown a reduced sepsisrelated mortality when animals were treated with tissue factor pathway inhibitor (TFPI) (for a review see Price et al., 2004). In a phase III clinical trial involving patients with severe sepsis, however, application of recombinant TFPI showed no evidence of a survival advantage (Abraham et al., 2003).

Streptococcus pyogenes is an important Gram-positive human pathogen that causes a wide array of diseases, ranging from mild infections such as pharyngitis and superficial skin infections, to life-threatening conditions such as necrotizing fasciitis and sepsis (Cunningham, 2000). In order to cause disease, the bacteria express a number of virulence factors, including $M$ proteins, which were as early as in 1969 described to render the bacterium resistant to phagocytosis by immune cells (Lancefield, 1969). M proteins form $\alpha$-helical coiled-coil dimers with a conserved C-terminal end and a highly variable $\mathrm{N}$-terminal end, based on which the streptococcal serotype is defined (for a review see Fischetti, 1989). Today, more than $80 \mathrm{M}$ serotypes have been identified, with the M1 and M3 type 
being the most common isolates from patients with invasive and toxic streptococcal diseases (for a review see Cunningham, 2000). M proteins are normally anchored to the cell membrane, but can be released from the bacterial surface by the action of host- or bacteria-derived proteinases (Berge \& Björck, 1995; Herwald et al., 2004). Thus, the present investigation was undertaken to study the effect of soluble M1 protein on pro-coagulant activity in human blood. Our results show that soluble M1 protein has a pronounced ability to trigger TF upregulation on the surface of human monocytes, which results in the induction of pro-coagulant activity in these cells.

\section{METHODS}

Reagents. M1 protein was purified from the growth medium of the isogenic mutant strain MC25, derived from the AP1S. pyogenes strain 40/58 (from the World Health Organization Collaborating Centre for References and Research on Streptococci, Institute of Hygiene and Epidemiology, Prague, Czech Republic). MC25 expresses a truncated M1 protein that lacks the membrane-spanning region, and the protein is therefore secreted into the growth medium (Collin \& Olsén, 2000). The purity of the M1 protein preparation was confirmed by SDS-PAGE followed by Coomassie and silver staining. The concentrations of peptidoglycan (PG) and lipoteichoic acid (LTA) in the stock solution of M1 protein $\left(0.5 \mu \mathrm{g} \mathrm{ml}^{-1}\right)$ were below detection limit $\left(<100 \mathrm{ng} \mathrm{PG} \mathrm{ml} \mathrm{m}^{-1}\right.$ and $<3 \mathrm{ng} \mathrm{LTA} \mathrm{ml}^{-1}$ ) as determined by mass spectrometry and ELISA, respectively (Påhlman et al., 2006). M3 protein, M5 protein, M49 protein, protein $\mathrm{H}$, peptostreptococcal albumin-binding protein (PAB), protein $\mathrm{L}$ and protein $\mathrm{M} 1$ fragments A-S and S-C3 were purified as previously described (de Chateau \& Björck, 1994; Kastern et al., 1992; Weineisen et al., 2004; Åkesson et al., 1994). Protein $G$ was obtained from Amersham Biosciences, protein A and LPS from Sigma-Aldrich.

Purification of peripheral blood mononuclear cells (PBMCs). PBMCs were isolated from fresh human heparinized blood from healthy volunteers. Blood was diluted $1: 1$ in PBS $(138 \mathrm{mM} \mathrm{NaCl}$, $8.1 \mathrm{mM} \mathrm{Na} \mathrm{HPO}_{4}, 2.7 \mathrm{mM} \mathrm{KCl}, 1.5 \mathrm{mM} \mathrm{KH}_{2} \mathrm{PO}_{4}, 0.5 \mathrm{mM} \mathrm{MgCl}$, $0.9 \mathrm{mM} \mathrm{CaCl}_{2}$; Gibco), layered on top of Ficoll-Paque Plus (Amersham Biosciences), and centrifuged at $1000 \mathrm{~g}$ for $20 \mathrm{~min}$ at room temperature. The PBMC cell layer was collected and cells were washed twice in PBS.

Clotting assays. Human heparinized blood $(250 \mu \mathrm{l})$ was treated with different bacterial compounds at $1 \mu \mathrm{g} \mathrm{ml}^{-1}$, various concentrations of $\mathrm{M} 1$ protein, or medium alone. After an overnight incubation on rotation at $37{ }^{\circ} \mathrm{C}$, cells were washed twice in $135 \mathrm{mM} \mathrm{NaCl}$, $12.9 \mathrm{mM}$ sodium citrate, $\mathrm{pH} \mathrm{7.4,} \mathrm{in} \mathrm{order} \mathrm{to} \mathrm{remove} \mathrm{the} \mathrm{plasma.}$ Next, $100 \mu \mathrm{l}$ of fresh and untreated human citrated plasma was reconstituted with $100 \mu \mathrm{l} 30 \mathrm{mM} \mathrm{CaCl}$. The reconstituted plasma was pre-warmed for $60 \mathrm{~s}$ at $37^{\circ} \mathrm{C}$ prior to the addition of $100 \mu \mathrm{l}$ of the washed cell suspension, and the time to form a clot was determined in a coagulometer. Alternatively, $250 \mu \mathrm{l}$ of PBMCs $\left(2.5 \times 10^{6} \mathrm{ml}^{-1}\right.$ in PBS) was incubated with various concentrations $\left(0.3-20 \mu \mathrm{g} \mathrm{ml}^{-1}\right)$ of M1 protein, fragments A-S or S-C3 (130 nM), or LPS (100 ng ml ${ }^{-1}$; Sigma-Aldrich) overnight at $37^{\circ} \mathrm{C}$, followed by the determination of pro-coagulant activity in normal or F VIIdeficient plasma (Hyphen BioMed) as described above. To analyse the intrinsic pathway of coagulation, $50 \mu \mathrm{l}$ of normal citrated or F VIIdeficient plasma was pre-incubated with $50 \mu \mathrm{l}$ of a kaolin-containing solution (Technoclone) for $60 \mathrm{~s}$ at $37{ }^{\circ} \mathrm{C}$. Clotting was initiated by adding $50 \mu \mathrm{l}$ of a $30 \mathrm{mM} \mathrm{CaCl}_{2}$ solution, and the time to form a clot was measured.
Flow cytometry. PBMCs $\left(250 \mu \mathrm{l}, 2.5 \times 10^{6} \mathrm{ml}^{-1}\right)$ in RPMI 1640 medium (Gibco) were treated with $\mathrm{M} 1$ protein $\left(1 \mu \mathrm{g} \mathrm{ml}{ }^{-1}\right.$ final concentration), LPS (100 ng ml ${ }^{-1}$ final concentration) or medium alone at $37{ }^{\circ} \mathrm{C}$ overnight. Cells were then washed in PBS including $2 \%(\mathrm{w} / \mathrm{v}) \mathrm{BSA}$, and incubated with mouse IgG (Sigma-Aldrich) for 30 min on ice to block unspecific binding of IgG. After two washing steps in PBS with $2 \%(\mathrm{w} / \mathrm{v})$ BSA, cells were incubated with FITCanti-TF IgG (American Diagnostica), a FITC-conjugated isotype control antibody (BD Biosciences), or R-phycoerythrin-anti-CD14 IgG (DAKO) for $30 \mathrm{~min}$ on ice. Samples were washed and analysed in a FACSCalibur flow cytometer (Becton Dickinson). Monocytes were identified by side scatter/forward scatter characteristics and CD14 expression (Loken et al., 1990).

Thin-sectioning and transmission electron microscopy. Purified

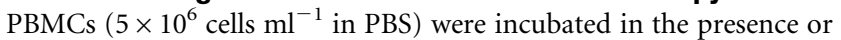
absence of M1 protein $\left(1 \mu \mathrm{g} \mathrm{ml}^{-1}\right)$ or fragment S-C3 $\left(0.34 \mu \mathrm{g} \mathrm{ml}^{-1}\right)$ for $20 \mathrm{~h}$ at $37{ }^{\circ} \mathrm{C}$. Afterwards, samples were mixed with pre-warmed $\mathrm{Ca}^{2+}$-reconstituted human plasma, and were allowed to form a clot. Clots were fixed for $1 \mathrm{~h}$ at room temperature and then overnight at $4{ }^{\circ} \mathrm{C}$ in $2.5 \%$ glutaraldehyde in $0.15 \mathrm{M}$ sodium cacodylate, pH 7.4 (cacodylate buffer). Samples were then washed with cacodylate buffer and post-fixed for $1 \mathrm{~h}$ at room temperature in $1 \%$ osmium tetroxide in cacodylate buffer, dehydrated in a graded series of ethanol, and then embedded in Epon 812 (SPI Supplies) using acetone as an intermediate solvent. When experiments were performed in the absence of calcium, cells were incubated with human plasma, centrifuged (12000 $\mathrm{g}$ for $30 \mathrm{~s}$ ) and resuspended in cacodylate buffer. Specimens were sectioned with a diamond knife into 50-70 nm-thick ultrathin sections on an LKB ultramicrotome. The ultrathin sections were stained with uranyl acetate and lead citrate. Specimens were observed in a JEOL JEM 1230 electron microscope operated at $80 \mathrm{kV}$ accelerating voltage. Images were recorded with a Gatan Multiscan 791 CCD camera.

\section{RESULTS}

\section{M1 protein induces pro-coagulant activity in human blood}

Disturbed blood coagulation is often seen in patients suffering from severe bacterial infections such as sepsis. In order to evaluate the role of different bacterial proteins in the induction of pro-coagulant activity, human whole blood was treated with surface proteins from various bacterial species and then tested in a clotting assay. After an overnight incubation, blood cells were washed to remove bacterial products and plasma proteins, and supplemented with fresh human plasma. Clotting was then initiated by recalcification, and the time to clot formation was determined in a coagulometer. Fig. 1(a) shows that $M$ proteins from serotypes M1, M3 and M49, but not M5, as well as the M-like protein $\mathrm{H}$ from Streptococcus pyogenes, induced pro-coagulant activity comparable to the response evoked by LPS. Treatment with protein A from Staphylococcus aureus and protein L from Finegoldia magna also decreased clotting times in whole blood, whereas protein $\mathrm{PAB}$ from F. magna and protein $\mathrm{G}$ from group $\mathrm{C}$ and $G$ streptococci gave no or only weak responses. Based on these findings, and the fact that the M1 serotype is one of the most frequently isolated serotypes from patients with severe and invasive streptococcal infections (Cunningham, 


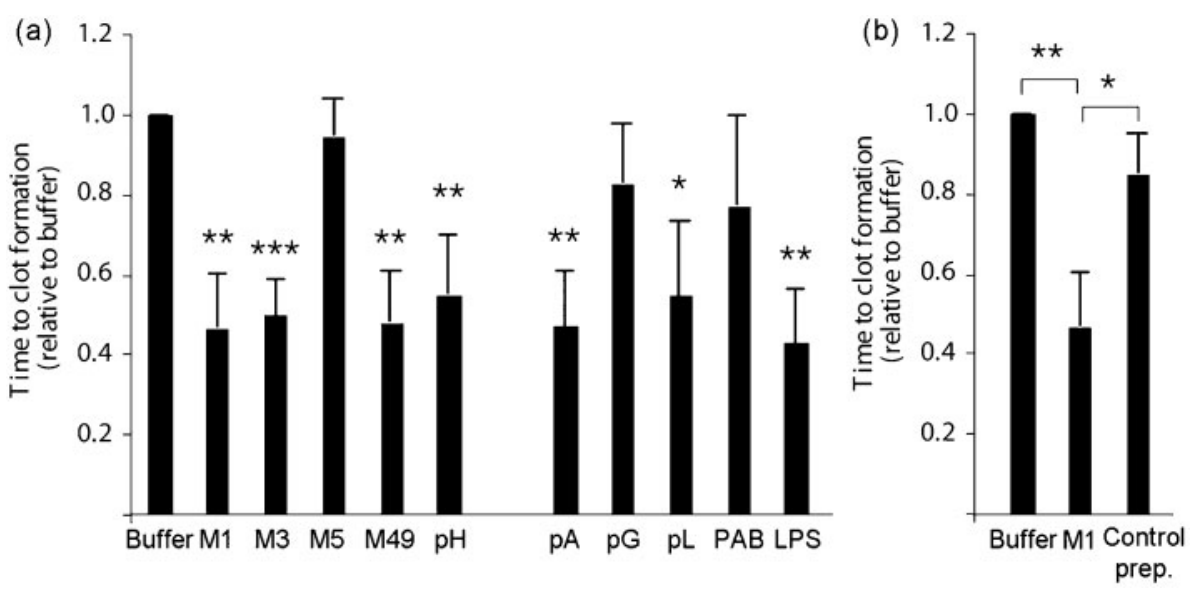

Fig. 1. Pro-coagulant activity of human blood in response to bacterial proteins. (a) Human blood was incubated overnight with $M$ proteins of different serotypes ( $M 1, M 3, M 5$ and $M 49)$, protein $H(p H)$, protein $A(p A)$, protein $G(p G)$, protein $L(p L), P A B$ or LPS at a final dilution of $1 \mu \mathrm{g} \mathrm{ml}^{-1}$. Samples were then washed, and $100 \mu \mathrm{l}$ of cell suspension was added to $100 \mu \mathrm{l}$ of prewarmed, fresh human citrated plasma, recalcified with $100 \mu \mathrm{CaCl}_{2}$. The time to form a clot was subsequently determined in a coagulometer and normalized to buffer-treated cells. (b) Human blood was treated with M1 protein $\left(1 \mu \mathrm{g} \mathrm{ml} \mathrm{m}^{-1}\right)$, the corresponding concentration of the control preparation, or buffer alone. After an overnight incubation, samples were washed and analysed as above. The values express clotting times relative to the clotting time evoked by buffer-treated cells. Values below 1 indicate increased pro-coagulant activity. Bars represent means and SD from three different donors. Asterisks indicate statistically significant differences as compared to buffer-treated cells, if not otherwise indicated: ${ }^{*}, P<0.05 ;{ }^{\star *}, P<0.01 ;{ }^{* \star *}$, $P<0.001$.

2000), M1 protein was chosen for further studies. It should be noted that the M1 protein that was used was purified from the growth medium of the isogenic M1 mutant strain MC25 that expresses a soluble M1 protein (Collin \& Olsén, 2000). To exclude that this preparation was contaminated with other soluble co-purified streptococcal products that may lead to an activation of the coagulation cascade, we subjected the growth medium from an isogenic M1 mutant strain (BMJ71, Kihlberg et al., 1995) that lacks M1 protein and protein $\mathrm{H}$ to the same purification protocol. This sample, here referred to as control preparation, was free of M1 protein as confirmed by ELISA, and gave rise to normal clotting times when added to whole blood (Fig. 1b). The findings imply that the ability to clot human blood was indeed evoked by M1 protein and not by a contaminant. The results also show that, apart from $M$ proteins, other factors derived from Gram-positive bacteria (i.e. protein A and protein $\mathrm{L}$ ) also have the ability to induce procoagulant activity in human blood. However, whether this was induced by the same mechanism as by M proteins was not addressed in the present study. In the next series of experiments, we wished to test whether the effect of M1 protein was dose-dependent. Thus, serial dilutions of M1 protein were added to human blood and the clotting times were determined. Fig. 2 shows that, at a concentration of $0.5 \mu \mathrm{g} \mathrm{ml}^{-1}$, M1 protein already induced a significant procoagulant activity in human blood, while a maximal effect was reached at $7.5 \mu \mathrm{g} \mathrm{ml}^{-1}$. Importantly, incubation of $\mathrm{M} 1$ protein with human plasma alone did not trigger pro-coagulant activity (data not shown), indicating that blood cells are required in this assay.

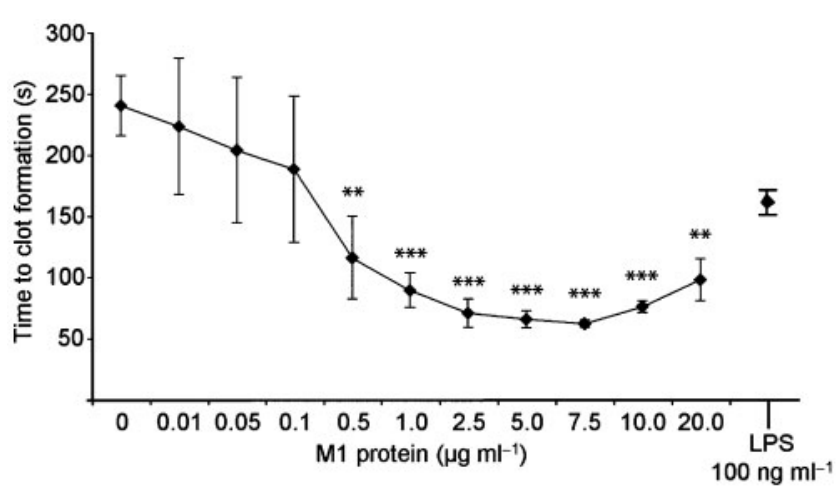

Fig. 2. M1 protein induces pro-coagulant activity in human blood. Human whole blood was treated with different concentrations of M1 protein. After $24 \mathrm{~h}$ incubation at $37{ }^{\circ} \mathrm{C}$, the samples were washed twice in order to remove $M 1$ protein and plasma components. Then $100 \mu$ fresh, untreated, citrated human plasma was pre-incubated with $100 \mu \mathrm{CaCl}_{2}$ at $37{ }^{\circ} \mathrm{C}$ for $60 \mathrm{~s}$ in a coagulometer. Washed blood cells $(100 \mu \mathrm{l})$ were added and the time to form a clot was determined. LPS $\left(100 \mathrm{ng} \mathrm{ml}^{-1}\right)$ served as a positive control. All samples were analysed in duplicates. The figure shows the mean $\pm S D$ of three individual experiments. **, $P<0.01 ;{ }^{* \star *}, P<0.001$. 


\section{Human monocytes upregulate tissue factor in response to M1 protein}

It is now generally believed that blood-borne TF is mainly produced by monocytes (Doshi \& Marmur, 2002). Based on our findings with whole blood, we wanted to test whether the interaction between M1 protein and peripheral blood mononuclear cells (PBMCs) is responsible for the induction of pro-coagulant activity in human blood. To that end, human PBMCs were isolated and treated with different concentrations of M1 protein for $20 \mathrm{~h}$. Cells were then added to fresh reconstituted human plasma, and the time to form a clot was determined. As seen in whole blood, treatment with $\mathrm{M} 1$ protein caused a significant and dose-dependent acceleration of clot formation (Fig. 3). No clotting was observed when normal plasma was replaced by F VII-deficient plasma (data not shown), implying that the pro-coagulant activity was mediated via the TF-dependent extrinsic pathway of coagulation. To ensure that the intrinsic pathway was still functional, the activated partial thromboplastin time (aPTT) of normal and F VII-deficient plasma was determined, which induced similar clotting times in both plasma samples (data not shown). Moreover, FACS scan analysis confirmed that monocytes upregulate TF in response to M1 protein (data not shown). To localize the domains of M1 protein that are responsible for the induction of pro-coagulant activity, PBMCs were incubated with M1 protein, or fragments A-S or S-C3, and tested in clotting assays. Fig. 4 shows that fragment A-S evoked normal clotting times, whereas fragment S-C3 was almost as potent as the full-length protein. These findings imply that M1 protein induces pro-coagulant activity via the TF-dependent extrinsic pathway, and that the carboxyterminal region, which is relatively well-conserved among different $\mathrm{M}$ serotypes, mediates this effect.

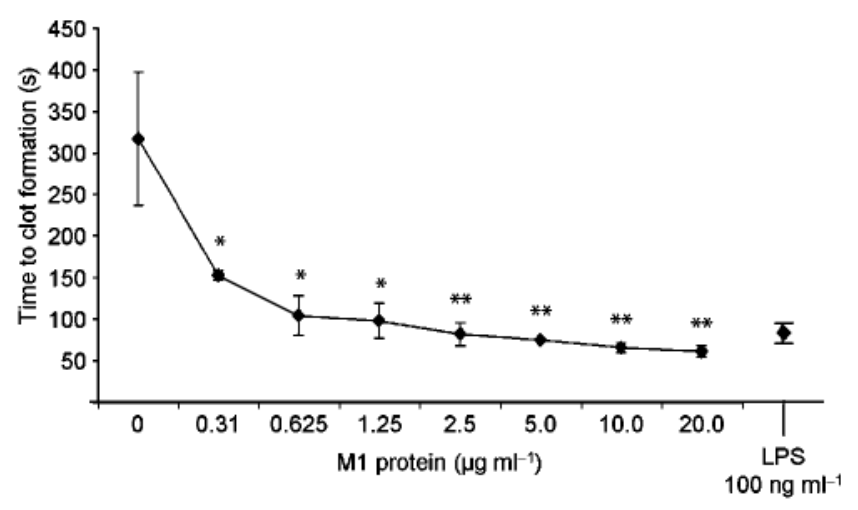

Fig. 3. $M 1$ protein induces pro-coagulant activity in human PBMCs. PBMCs were isolated from human blood and incubated with $\mathrm{M} 1$ protein at different concentrations or $100 \mathrm{ng} \mathrm{LPS} \mathrm{ml}^{-1}$ for $24 \mathrm{~h}$ at $37^{\circ} \mathrm{C}$. Cell suspensions $(100 \mu \mathrm{l})$ were then added to $100 \mu \mathrm{l}$ of pre-warmed citrated human plasma, recalcified with $100 \mu \mathrm{CaCl}_{2}$, and the time to form a clot was measured. Values represent the mean \pm SD of three separate experiments, each done in duplicates. ${ }^{*}, P<0.05$ and ${ }^{* *}, P<0.01$.

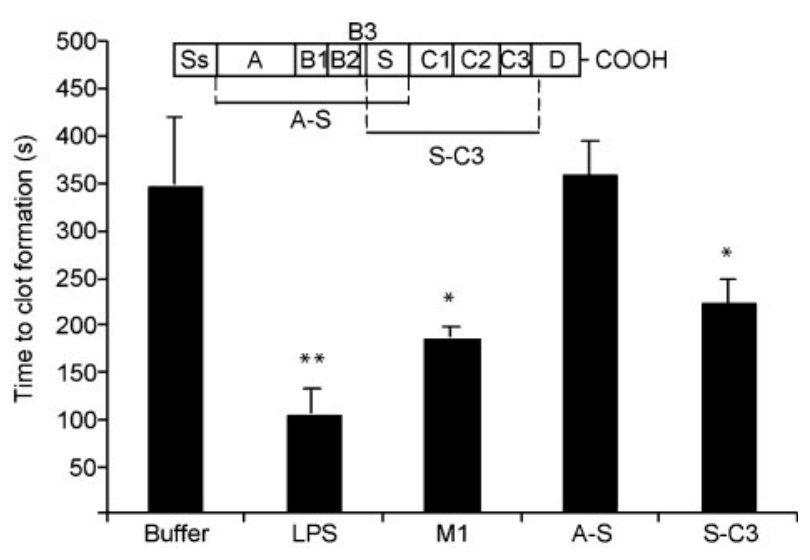

Fig. 4. Pro-coagulant activity induced by $M 1$ protein fragments. Human PBMCs $\left(1 \times 10^{6} \mathrm{ml}^{-1}\right)$ were incubated with $\mathrm{M} 1$ protein $\left(5 \mu \mathrm{g} \mathrm{ml}^{-1}\right)(130 \mathrm{nM})$, fragments $\mathrm{A}-\mathrm{S}$ or S-C3 at equimolar concentrations (2.0 and $1.7 \mathrm{\mu g} \mathrm{ml}^{-1}$, respectively), LPS (100 ng $\mathrm{ml}^{-1}$ ) or buffer alone for $20 \mathrm{~h}$ at $37{ }^{\circ} \mathrm{C}$, and the ability of the cell suspensions to induce clot formation was thereafter determined in a coagulometer. The figure shows the mean $\pm S D$ of three individual experiments. Asterisks indicate statistically significant differences relative to buffer control cells: ${ }^{*}, P<0.05 ;{ }^{\star *}, P<0.01$. Fragments A-S and S-C3 are schematically depicted at the top.

\section{Monocytes activated by M1 protein are coated by a fibrin network}

To visualize the effect on clot formation of treating PBMCs with $\mathrm{M} 1$ protein, thin sectioning and transmission electron microscopy were employed. PBMCs were incubated with M1 protein or fragment S-C3 overnight, followed by reconstitution with normal plasma in the absence or presence of calcium (Fig. 5d-g). As controls, PBMCs incubated with normal plasma in the absence of M1 protein or fragment S-C3 (Fig. 5b, c), and untreated PBMCs (Fig. 5a), were used. Samples were subsequently fixed, thin sectioned, and analysed by electron microscopy. Fig. 5(e) shows that fibrin polymerization appears to be initiated at the surface of M1 protein-treated monocytes, whereas unstimulated cells were not in contact with the fibrin network (Fig. 5c). In order to verify that the fibrils consisted of fibrin and not of M1 protein in complex with fibrinogen, cells were stimulated with fragment S-C3, which lacks the fibrinogen-binding site (Åkesson et al., 1994). Similar to M1 protein-treated PBMCs, cells stimulated with fragment S-C3 were in contact with surrounding fibrils (Fig. 5 g). Moreover, when the experiments were conducted in the absence of calcium in order to prevent fibrin polymerization, no aggregates were found attached to PBMCs (Fig. 5b, d and f). Taken together, these findings imply that M1 protein can stimulate monocytes to express TF on the cell surface, which in turn serves as an initiation point for fibrin polymerization. 


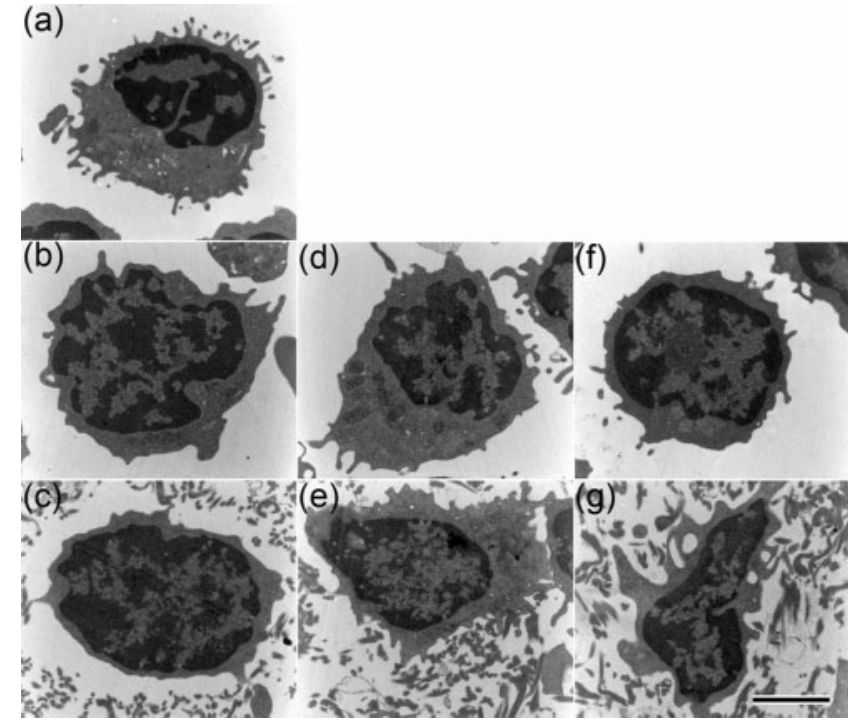

Fig. 5. Monocytes treated with $M 1$ protein form a fibrin network on the cell surface. PBMCs untreated $(b, c)$ or stimulated with $M 1$ protein $\left(1 \mu \mathrm{g} \mathrm{ml}^{-1}\right)(\mathrm{d}, \mathrm{e})$ or fragment $\mathrm{S}-\mathrm{C} 3(\mathrm{f}, \mathrm{g})$ were incubated with human plasma in the absence $(b, d, f)$ or presence $(c, e, g)$ of $\mathrm{Ca}^{2+}$. Pelleted cells $(b, d, f)$ and clots $(c, e, g)$ were fixed, thinsectioned, and examined by transmission electron microscopy as described in Methods. Monocytes that were not incubated with plasma served as control (a). Bar, $2 \mu \mathrm{m}$.

\section{DISCUSSION}

The extrinsic or TF-driven pathway of coagulation is regarded as the most important initiation step of the clotting cascade in vivo, and the expression of TF is under normal conditions tightly regulated in order to preserve an intact haemostasis (Mackman, 2006). This situation is altered in severe inflammatory conditions, where proinflammatory mediators such as cytokines, C-reactive protein and bacterial endotoxin can induce a systemic upregulation of TF on blood-borne monocytes (Opal \& Esmon, 2003). It is now generally believed that these interactions play a key role in the pathogenesis of sepsisrelated complications such as the coagulopathy DIC. Moreover, accumulating evidence suggests that TF is also an important modulator of inflammation (Cunningham et al., 1999). For example, mice deficient in TF express significantly lower levels of IL-6 in response to LPS than wild-type animals (Pawlinski et al., 2004). Other studies have shown that active site-inhibited F VIIa (F VIIai) and TFPI reduce the expression of pro-inflammatory cytokines IL-6 and IL-8 in vivo, decrease coagulation and thereby prevent death in a lethal baboon model of Escherichia coliinduced sepsis (Creasey et al., 1993; Taylor et al., 1998). The pro-inflammatory properties of TF involve proteaseactivated receptor 2 (PAR-2), which is activated by the TF/ F VIIa and TF/F VIIa/F Xa complexes, as well as by F Xa alone (Camerer et al., 2000, 2002). Thus, inflammation and coagulation are intimately connected, and the upregulation of TF under pro-inflammatory conditions is considered as an important mediator of the crosstalk between these two processes.

S. pyogenes is one of the most common human pathogens and is responsible for an estimated 616 million cases of pharyngitis and 111 million cases of pyoderma worldwide every year (Carapetis et al., 2005). In addition to these superficial infections, the bacterium is believed to cause 663000 cases of invasive diseases, resulting in 163000 deaths, annually (Carapetis et al., 2005). Although rare, invasive streptococcal infections are feared conditions in intensive care medicine due to mortality rates ranging from 25 to $70 \%$ (Carapetis et al., 2005; Stevens, 2003). The pathogenesis of invasive streptococcal infections is often associated with an overamplification of the innate immune system. Notably, even though streptococcal interactions with so-called human effector systems have been studied intensively over the last two decades (for a review see Bisno et al., 2003), the reasons why some, but not all, S. pyogenes infections develop into these devastating conditions are still obscure. It has been, however, speculated that gene polymorphisms both in streptococci and the human host could contribute to the severity of the disease. For instance, Beres et al. (2006) recently reported that gene polymorphisms, likely to influence M3 protein expression or function, seem to affect the ability of $S$. pyogenes to cause invasive disease, and Kotb et al. (2002) reported that variations in MHC class II alleles/haplotypes influence the outcome of invasive streptococcal infectious diseases. A genetic association study performed by Sutherland et al. (2005) revealed that a special tlr2 genotype (16933AA) is associated with significantly increased prevalence of sepsis on admission to the intensive care unit, and specifically increased prevalence of Gram-positive sepsis. Recently, we showed that M1 protein interacts with human monocytes via TLR2 (Toll-like receptor 2) (Påhlman et al., 2006). Since TF expression is under the control of transcription factors such as nuclear factor $\kappa \mathrm{B}(\mathrm{NF} \kappa \mathrm{B})$ (Guha et al., 2001), which is also activated by TLR2 (Roeder et al., 2004), it is tempting to speculate that $t l r 2$ polymorphisms may influence the severity of coagulation disorders in invasive streptococcal infections.

Several epidemiological studies have shown that severe infections caused by $S$. pyogenes are associated with certain serotypes, with the M1 and M3 serotypes as the most prevalent (Stevens, 1992). Although an induction of the coagulation system is a common feature of these devastating conditions, little is known about the molecular mechanisms employed by streptococci to impair normal haemostasis. Bryant et al. (2003) reported that heat-killed S. pyogenes bacteria of serotypes M1 and M3, but not M6, have the ability to stimulate TF and cytokine induction in endothelial cells and monocytes. Our findings that M1 protein alone induces TF-expression in monocytes support these data and show an important role for M proteins in coagulation disorders. Moreover, our data show that $S$. 
pyogenes bacteria have developed a mechanism that evokes coagulation dysfunction that is not restricted to the site of infection and may result in a systemic activation of the coagulation system. Thus, taken together, our data further emphasize the ability of $\mathrm{M}$ protein to induce inflammation and thrombosis, and may help to explain the pathogenesis of sepsis and DIC.

\section{ACKNOWLEDGEMENTS}

We wish to thank Monica Heidenholm and Maria Baumgarten for excellent technical assistance. This work was supported in part by the foundations of Alfred Österlund, Clas Groschinsky, Crafoord, Greta and Johan Kock, the Royal Physiographical Society in Lund, the Odd Fellow Sweden, the Blood and Defence Network and the Vascular Wall Programme at Lund University, the Medical Faculty, Lund University, the Swedish Research Council (projects 7480 and 13413), and Hansa Medical AB.

\section{REFERENCES}

Abraham, E., Reinhart, K., Opal, S., Demeyer, I., Doig, C., Rodriguez, A. L, Beale, R., Svoboda, P., Laterre, P. F. \& other authors (2003). Efficacy and safety of tifacogin (recombinant tissue factor pathway inhibitor) in severe sepsis: a randomized controlled trial. JAMA 290 , 238-247.

Åkesson, P., Schmidt, K. H., Cooney, J. \& Björck, L. (1994). M1 protein and protein $\mathrm{H}$ : IgGFc- and albumin-binding streptococcal surface proteins encoded by adjacent genes. Biochem J 300, 877-886.

Beres, S. B., Richter, E. W., Nagiec, M. J., Sumby, P., Porcella, S. F., Deleo, F. R. \& Musser, J. M. (2006). Molecular genetic anatomy of inter- and intraserotype variation in the human bacterial pathogen group A Streptococcus. Proc Natl Acad Sci U S A 103, 7059-7064.

Berge, A. \& Björck, L. (1995). Streptococcal cysteine proteinase releases biologically active fragments of streptococcal surface proteins. J Biol Chem 270, 9862-9867.

Bisno, A. L., Brito, M. O. \& Collins, C. M. (2003). Molecular basis of group A streptococcal virulence. Lancet Infect Dis 3, 191-200.

Bryant, A. E., Hayes-Schroer, S. M. \& Stevens, D. L. (2003). M type 1 and 3 group A streptococci stimulate tissue factor-mediated procoagulant activity in human monocytes and endothelial cells. Infect Immun 71, 1903-1910.

Camerer, E., Huang, W. \& Coughlin, S. R. (2000). Tissue factor- and factor X-dependent activation of protease-activated receptor 2 by factor VIIa. Proc Natl Acad Sci U S A 97, 5255-5260.

Camerer, E., Kataoka, H., Kahn, M., Lease, K. \& Coughlin, S. R. (2002). Genetic evidence that protease-activated receptors mediate factor Xa signaling in endothelial cells. J Biol Chem 277, 16081-16087.

Carapetis, J. R., Steer, A. C., Mulholland, E. K. \& Weber, M. (2005). The global burden of group A streptococcal diseases. Lancet Infect Dis 5, 685-694.

Collin, M. \& Olsén, A. (2000). Generation of a mature streptococcal cysteine proteinase is dependent on cell wall-anchored M1 protein. Mol Microbiol 36, 1306-1318.

Creasey, A. A., Chang, A. C., Feigen, L., Wun, T. C., Taylor, F. B., Jr \& Hinshaw, L. B. (1993). Tissue factor pathway inhibitor reduces mortality from Escherichia coli septic shock. J Clin Invest 91, 2850-2860.

Cunningham, M. A., Romas, P., Hutchinson, P., Holdsworth, S. R. \& Tipping, P. G. (1999). Tissue factor and factor VIIa receptor/ligand interactions induce proinflammatory effects in macrophages. Blood 94, 3413-3420.

Cunningham, M. W. (2000). Pathogenesis of group A streptococcal infections. Clin Microbiol Rev 13, 470-511.

de Chateau, M. \& Björck, L. (1994). Protein PAB, a mosaic albuminbinding bacterial protein representing the first contemporary example of module shuffling. J Biol Chem 269, 12147-12151.

Doshi, S. N. \& Marmur, J. D. (2002). Evolving role of tissue factor and its pathway inhibitor. Crit Care Med 30, S241-S250.

Fischetti, V. A. (1989). Streptococcal M protein: molecular design and biological behavior. Clin Microbiol Rev 2, 285-314.

Guha, M., O'Connell, M. A., Pawlinski, R., Hollis, A., McGovern, P., Yan, S. F., Stern, D. \& Mackman, N. (2001). Lipopolysaccharide activation of the MEK-ERK1/2 pathway in human monocytic cells mediates tissue factor and tumor necrosis factor alpha expression by inducing Elk-1 phosphorylation and Egr-1 expression. Blood 98, 1429-1439.

Herwald, H., Cramer, H., Mörgelin, M., Russell, W., Sollenberg, U., Norrby-Teglund, A., Flodgaard, H., Lindbom, L. \& Björck, L. (2004). $M$ protein, a classical bacterial virulence determinant, forms complexes with fibrinogen that induce vascular leakage. Cell 116, 367-379.

Kastern, W., Sjöbring, U. \& Björck, L. (1992). Structure of peptostreptococcal protein $\mathrm{L}$ and identification of a repeated immunoglobulin light chain-binding domain. J Biol Chem 267, $12820-12825$.

Kihlberg, B. M., Cooney, J., Caparon, M. G., Olsén, A. \& Björck, L. (1995). Biological properties of a Streptococcus pyogenes mutant generated by Tn916 insertion in mga. Microb Pathog 19, 299-315.

Kotb, M., Norrby-Teglund, A., McGeer, A., El-Sherbini, H., Dorak, M. T., Khurshid, A., Green, K., Peeples, J., Wade, J. \& other authors (2002). An immunogenetic and molecular basis for differences in outcomes of invasive group A streptococcal infections. Nat Med $\mathbf{8}$, 1398-1404.

Lancefield, R. C. (1969). Current problems in studies of streptococci. J Gen Microbiol 55, 161-163.

Levi, M., de Jonge, E. \& van der Poll, T. (2003). Sepsis and disseminated intravascular coagulation. J Thromb Thrombolysis 16, 43-47.

Loken, M. R., Brosnan, J. M., Bach, B. A. \& Ault, K. A. (1990). Establishing optimal lymphocyte gates for immunophenotyping by flow cytometry. Cytometry 11, 453-459.

Mackman, N. (2006). Role of tissue factor in hemostasis and thrombosis. Blood Cells Mol Dis 36, 104-107.

Opal, S. M. \& Esmon, C. T. (2003). Bench-to-bedside review: functional relationships between coagulation and the innate immune response and their respective roles in the pathogenesis of sepsis. Crit Care 7, 23-38.

PåhIman, L. I., Mörgelin, M., Eckert, J., Johansson, L., Russell, W., Riesbeck, K., Soehnlein, O., Lindbom, L., Norrby-Teglund, A. \& other authors (2006). Streptococcal M protein: a multipotent and powerful inducer of inflammation. J Immunol 177, 1221-1228.

Pawlinski, R., Pedersen, B., Schabbauer, G., Tencati, M., Holscher, T., Boisvert, W., Andrade-Gordon, P., Frank, R. D. \& Mackman, N. (2004). Role of tissue factor and protease-activated receptors in a mouse model of endotoxemia. Blood 103, 1342-1347.

Price, G. C., Thompson, S. A. \& Kam, P. C. (2004). Tissue factor and tissue factor pathway inhibitor. Anaesthesia 59, 483-492.

Riedemann, N. C., Guo, R. F. \& Ward, P. A. (2003). Novel strategies for the treatment of sepsis. Nat Med 9, 517-524.

Roeder, A., Kirschning, C. J., Schaller, M., Weindl, G., Wagner, H., Korting, H. C. \& Rupec, R. A. (2004). Induction of nuclear factor- $\kappa$ B 
and c-Jun/activator protein-1 via Toll-like receptor 2 in macrophages by antimycotic-treated Candida albicans. J Infect Dis 190, 1318-1326.

Stevens, D. L. (1992). Invasive group A Streptococcus infections. Clin Infect Dis 14, 2-11.

Stevens, D. L. (2003). Group A streptococcal sepsis. Curr Infect Dis Rep 5, 379-386.

Sutherland, A. M., Walley, K. R. \& Russell, J. A. (2005). Polymorphisms in CD14, mannose-binding lectin, and Toll-like receptor- 2 are associated with increased prevalence of infection in critically ill adults. Crit Care Med 33, 638-644.

Taylor, F. B., Chang, A. C., Peer, G., Li, A., Ezban, M. \& Hedner, U. (1998). Active site inhibited factor VIIa (DEGR VIIa) attenuates the coagulant and interleukin- 6 and -8 , but not tumor necrosis factor, responses of the baboon to LD100 Escherichia coli. Blood 91, 1609-1615.

Van Amersfoort, E. S., Van Berkel, T. J. \& Kuiper, J. (2003). Receptors, mediators, and mechanisms involved in bacterial sepsis and septic shock. Clin Microbiol Rev 16, 379-414.

Weineisen, M., Sjöbring, U., Fallman, M. \& Andersson, T. (2004). Streptococcal M5 protein prevents neutrophil phagocytosis by interfering with $\mathrm{CD} 11 \mathrm{~b} / \mathrm{CD} 18$ receptor-mediated association and signaling. J Immunol 172, 3798-3807.

Edited by: T. Msadek 